\title{
The Possibilities of the Application of the Krajewski's Method (2012) in the Assessment of the Impact of the Wind Investments on the Landscape
}

\author{
Iwona Dominika Orzechowska-Szajda ${ }^{1 *}$, Magdalena Młynarczyk², \\ Kazimierz Chmura ${ }^{3}$, Maciej Piotrowski ${ }^{3}$ \\ ${ }^{1}$ Institute of Landscape Architecture, Wrocław University of Environmental and Life Sciences \\ Grunwaldzka 55, 50-357 Wrocław, Polska \\ ${ }^{2}$ Environmental Management Department, Wrocław University of Technology, Poland \\ ${ }^{3}$ Institute of Landscape Architecture, Wrocław University of Environmental and Life Sciences, Poland
}

Received: 4 August 2017

Accepted: 18 September 2017

\begin{abstract}
The dissertation attempts to determine the applicability of one of the newest assessment methods of the landscape capacity as a tool supporting the assessment of the investments' impact on the landscape. For the purpose of the research a Wind farm (PROMET-PLAST S.C.) was chosen, which is located in the Gaj Oławski village on a hill, at the Provincial Road No. 396, on the Oława-Strzelin route, Lower Silesian Voivodeship, Oława County.

In the process of the assessment of the wind farm's impact on the landscape, the photographic documentation was used of the panoramas from 16 observation points designated in places where the visibility zone circle and the communication route cross.

The Krajewski's method of the assessment of the landscape capacity was used (2012), which constituted the starting point for the studies. The following criteria for this assessment were adopted: the terrain construction, the land cover and visibility. The landscape capacity arising from the historical value (the higher the historical value, the lesser the landscape capacity), visual values (related to the topographic conditions) and the exposure (active and passive one) was examined.

The method applied did not fully allow to determine the overall landscape capacity. However, its use during the phase of the investment preparation (the choice of location in the field), through the appropriate location depending on the type of landscape, topography, spatial relationships, can minimize the potential negative impact.
\end{abstract}

Keywords: Wind Farm, landscape investment, capacity assessment

*e-mail: iwona.orzechowska-szajda@up.wroc.pl 


\section{Introduction}

Renewable Energy Technologies Have Received Strong Political Support Since the 1990s in many parts of the world because of their contribution to mitigating climate change, helping to meet rising energy demand, and increasing energy security [1]. Energy generation is one of the main causes of greenhouse gas emissions [1-3]. Wind farms are an important source of renewable energy around the world. Wind turbines have low carbon emissions, and it is suggested that half of the world demand for energy could theoretically be met by wind energy by 2030 [4-5]. According to the records of the Directive 2009/28/EC of 23 April 2009 on the promotion of the use of energy from renewable sources in the European Union as a whole, including Poland, the development of the energy acquired from natural sources is necessary. All EU Member States are obliged to take into account renewable energy sources in the administrative regulations related to environmental protection and climate change [6]. For this reason, Polish energy policy must also inevitably switch to a very dynamic development of wind energy [7].

Social acceptance is one of the challenges for implementing wind energy. Psychological studies on the acceptance of wind turbines on the landscape by society were conducted early in the 21 st century [8-14]. According to UK research, $63 \%$ of the population is in favor of wind turbines, $28 \%$ have sustainable views, $5 \%$ are against wind farms, and $4 \%$ have not formed a definite opinion on the subject $[13,15]$. Scientific research in the world indicates that the visual qualities of wind power plants have a significant impact on acceptance by society of such an investment in the landscape [14, 16-21]. Many studies have indicated that wind investment is negatively perceived by society as introducing the disharmonious into space [22], or that it raises negative reactions such as anger and surprise [23-25]. Undoubtedly, one of the most interesting methods of generating energy from renewable sources is establishing wind farms. Among the advantages of wind energy, what should be listed first and foremost is an inexhaustible source as well as the purity of energy, the production of which does not entail the emissions of toxic compounds into the atmosphere or the generation of waste [5, 25-28]. The lack of fees for wind is also an advantage. From the aesthetic point of view, the spinning turbines of fans constitute a less blemishing element of the landscape than smoking chimneys. The wind farms have also positive aspects in a social context. The ability to use small turbines gives us the chance to produce electricity and thus improve living conditions for people in areas where the main current does not reach. Research based on the evaluation of psychophysical response to displayed images using SCR organized by Franta'l and Kunc [29] or Maeh at al. [13] have also shown that from an aesthetic point of view wind turbines are a less disparaging element of the landscape than smoking chimneys, power plants, or electrical poles.

Unfortunately, the source literature also provides many examples of the negative impact of these investments on the environment $[5,7]$, particularly on flying animals, including bats [30-37]. What is mainly indicated are the collisions of birds and bats with turbines, the loss of natural habitat, and the need to change some behaviours of species by forcing them to avoid farms that have been constructed on migration routes [38]. There are, however, scientific studies that prove the fears of bird lovers to be unreasonable [39-41].

Between 2011 and 2014, the number of scientific publications on the impact of wind farms on human health has also increased six times [12-13, 42-43]. Torrance and Goff [44], Fiumicelli [45], Lee et al. [46], Pedersen [47], Bakker et al. [24], and Maffei et al. [20] also conducted studies on noise levels produced by wind turbines and their negative impact on human life. The most recent of these, by Bakker [24], has shown that visual effects also affect the perceived noise level.

Among Polish publications, few dissertations exist on assessing the impact of wind farms on the landscape and the visual environment. According to Malczyk [48] and Badora [38], the negative socio-spatial and landscape aspects include:

- Damage caused by the ground works carried out in order to occupy the land where a wind farm, roads, and other infrastructure elements are to be constructed.

- Changing the terrain relief (after the completion of the construction works, the area is partly subject to rehabilitation), the transformation of the top layer of the geological sediments and soil.

- The implementation of new landmarks in the form of turbines and adding the dynamics to the landscape through the rotary movement of blades.

- Changes in biocenosis related to the felling of vegetation, converting the adjacent ecosystems.

- The emergence of such adverse effects as: casting shadows, reflecting stroboscopic light, and emitting light pulses at night.

- Changes to the physical state of the atmosphere by noise emission, electrical and magnetic fields, infrasounds, vibrations (it is assumed that for one turbine with a power of 1.5-2.5 mw the oversize impact of noise, depending on the background and nature of the landscape, occurs at a range of 250-350 m).

- Throwing ice by the turbines in late fall, winter and early spring, when after the downtime period a rotor is run (the hazard zone does not exceed twice the height of the turbine, and during downtime the risk only occurs under the blades).

Therefore, in the age of strong pressure on investments in wind farms, it becomes necessary to know the impact of large-scale investments on the existing landscape and the level of their acceptance in society already at the stage of designing [13, 49]. Swim et al. [11] and Tsoutsos et al. [50] also highlight the need for research into a wind turbine's impact on the visual environment; they believe that psychological research can contribute to the change in climate change by changing societal attitudes.

The proponents of wind power plants focus primarily on the environmental benefits [13]. Many highly 
developed countries with a rich tradition of the landscape architecture, such as the United Kingdom, the United States of America, Canada, or Australia have developed legal procedures, that is landscape management systems (visual systems management), the purpose of which is the objective and uniform assessment of the impact of a potential investment on the landscape [49, 51-57]. Numerous scientific studies on visual impact assessment of wind power plants, based on public opinion research $[12,14,17]$, statistical analyses, and multicriteria analyzes [6] using GIS tools [6, 18, 26-27, 50, 58-59] have been published in the scientific literature.

In recent years, also in the Polish scientific community, the interest in issues concerning assessment and valorisation of the landscape is gradually increasing. Many works depicting a variety of methodological approaches to the issue of the landscape assessment have been developed [60-65].

Changes to the EIA directive adopted in April 2014 by the European Parliament impose an obligation to assess the visual impact of investments on the landscape under the environmental impact assessment procedure. These assessments are designed to better preserve Europe's cultural and landscape heritage. On 11 September 2015 the act (dated April 24, 2015) amending some of the acts concerning the strengthening of landscape conservation tools came into force. This Act is commonly known as "the landscape act." Currently experts discuss the scope and the methodology for the preparation of the landscape audit, which is a tool formalized by the above-mentioned act and which aims to identify landscapes that occur on the territory of the voivodeship in order to determine the features and evaluate their values. In the course of the discussion, new methods of evaluating the impact of investments on the landscape have appeared, including the methodology of the assessment of the wind farms' impact on the landscape by Krzysztof Badora from the Faculty of Land Surface Protection of Opole University [66]. It would be a legal procedure in force in Poland, but it constitutes a very complex, time-consuming, and costly tool.

The purpose of this article is to define the applicability of one of the newest methods, that is the method of

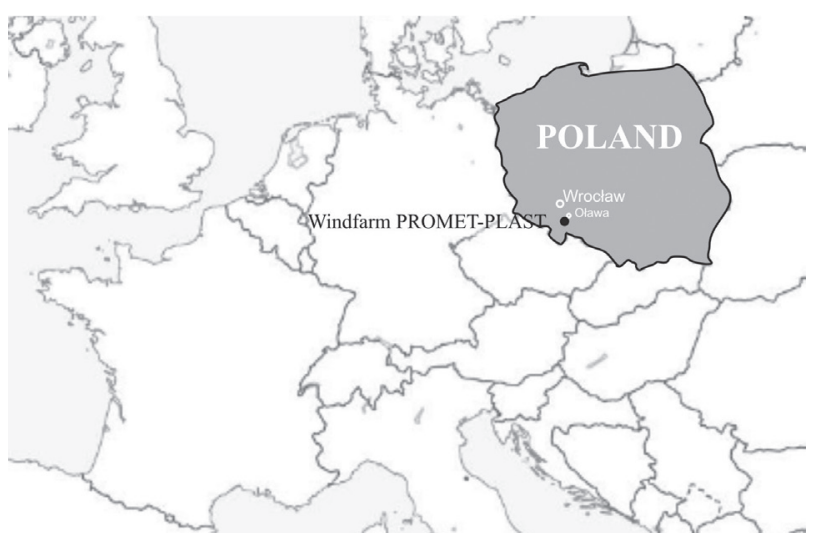

Fig.1. Location of the research area. landscape capacity assessment in the process of the assessment of the impact of a wind farm on the landscape based on the example of the PROMET PLAST S.C. Windfarm near Oława in the Lower Silesian Voivodeship. The research presented in the dissertation constitutes one of the opinions in the discussion of the exploration of tools supporting the assessment of the impact of the investment on the landscape.

\section{Materials and Methods}

\section{Field Studies}

The research subject is located in Gaj Oławski, approximately $5.5 \mathrm{~km}$ southwest of Olawa. This area is located in the Lower Silesia Voivodeship in the in Oława County (Fig. 1). The investment of Windfarm PROMETPLAST S.C. is located on a hill, at Provincial Road No. 396 on the Olawa-Strzelin route. The aim of the fieldwork was to acquire photographic documentation, which constitutes the starting point for the study. The panoramas were made using a Canon Digital Ixus 95 IS digital camera in summer 2016 under stable lighting conditions.

Due to the fact that the impact of the investment varies together with the change of the observation distance, the inventory was made either directly from the wind farm site and from the access roads. To do this, on the basis of the zone of visual influence method [67], the three zones of visibility were designated: up to $2 \mathrm{~km}$ (solid line), up to $5 \mathrm{~km}$ (dashed line), and up to $10 \mathrm{~km}$ (point line) (Fig. 2).

The power of investment impact also changes together with the increase in the number of its observers. Therefore, the communication routes were defined as the largest observational corridors from which the investment is visible. For this purpose, the roads of medium and high traffic frequency were chosen, that is National Road Nos. 94 and 39, and Provicial Road Nos.

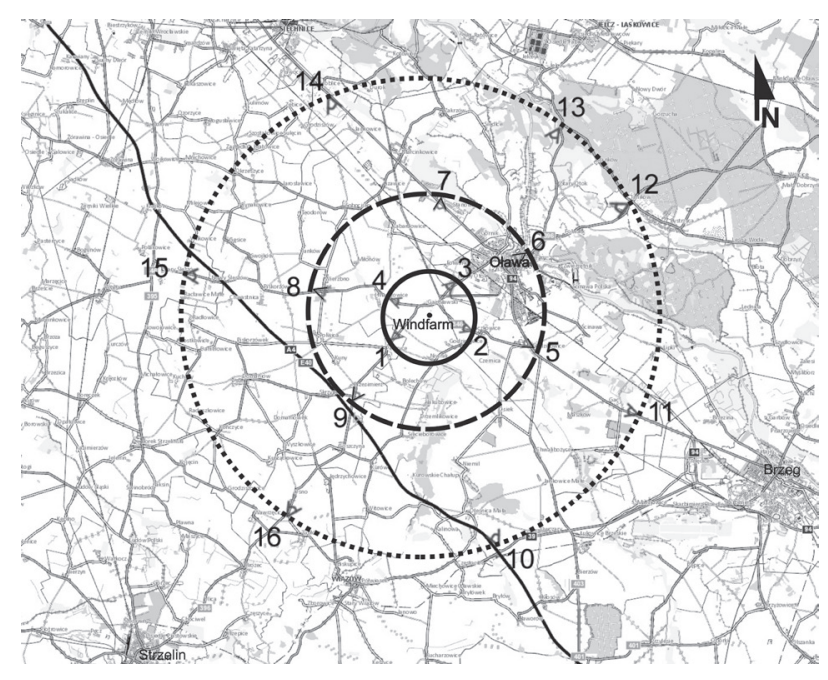

Fig.2 The designated visibility zones and observation points (prepared by the author). 
396, 346, and 455. Places where the visibility zone and communication routes cross constituted the points from which the panoramas were made. In this way, a total of 16 such observation points were designated (Fig. 2).

\section{Studies of Landscape Capacity}

The lexicon of geoecology and landscape protection [68] defines landscape capacity as "... the ability to accept the burden related to human activity ...." Therefore, landscape capacity is correlated with the degree of the possibility of changes to it. In the study we used Krajewski's assessment method of landscape capacity [64]. This method should be used in environmental research, which has already been subject to human pressure through, for example, spatial planning.

The first step of research was to conduct the assessment of landscape absorbency, which is "the ability to accept new elements without losing the identity of its physiognomy." The following criteria for evaluating landscape absorbency were adopted: land cover and visibility. For determining landscape capacity the following types of assessment are taken into account:

- Assessment resulting from historical value (the higher the historical value, the less the landscape capacity).

- Visual assessment related to topographical conditions.

- Assessment resulting from exposure - both active and passive one [64].

Any deviation from the criterion show the variability of processes that take place in the landscape. To determine these variations the following actions were to be performed:

- Preparing land cover maps for at least three time periods, and the calculation - in hectares and percentages - on the basis of the contributions of the land cover types in relation to the entire area subject to research.

- Designating the percentage degree of deviation; this is the share of individual types of land cover between each time duration (assumption: the surface of a given type of land cover for reference criterion $=0$, the change in value relative to the initial value of $1 \%$, for the entire surface of the area subject to research is equal to the deviation of +1 or -1 ).

- Adding up the absolute values received of the degree of deviation for all types of land cover, which was the method of specifying the indicator of landscape variation, which is the basis for determining landscape capacity resulting from historical value.

The maps that had been made helped determine the area occupied by particular land cover types, that is: housing construction, farmland, and vegetation. The results obtained, in hectares, had been converted into the percentage share, thanks to which the degree of deviation was specified. On this basis, the indicator of the landscape variation resulting from historical value was designated. As a result of the analyses conducted, the database was obtained containing the historical and current land cover and indicating the areas with small landscape changes as well as such where the changes were significant.
Table 1. Matrix of values for terrain construction [64, p. 27].

\begin{tabular}{|c|c|c|c|c|}
\hline \multirow{2}{*}{\multicolumn{2}{|c|}{$\begin{array}{c}\text { Slope aspects } \\
\text { average decrease }\end{array}$}} & Southern slope & $\begin{array}{l}\text { Eastern, western } \\
\text { slope }\end{array}$ & Northern slope \\
\hline & & 3 points & 2 points & 1 point \\
\hline area $8 \%$ & 3 & 6 points & 5 points & 4 points \\
\hline $4-8 \%$ & 2 & 5 points & 4 points & 3 points \\
\hline $0-4 \%$ & 1 & 4 points & 3 points & 2 points \\
\hline
\end{tabular}

Table 2. Matrix of values for average height of vegetation and buildings [64, p. 27].

\begin{tabular}{l|c|c|c|c|}
\multicolumn{2}{l}{$\begin{array}{l}\text { Average height of vegetation - } \\
\text { the number of tiers }\end{array}$} & $<1 \mathrm{~m}$ & $1-5 \mathrm{~m}$ & $>5 \mathrm{~m}$ \\
\cline { 3 - 5 } & & 3 & 2 & 1 \\
\hline 1 & 3 & 6 points & 5 points & 4 points \\
\hline 2 & 2 & 5 points & 4 points & 3 points \\
\hline$>2$ & 1 & 4 points & 3 points & 2 points \\
\hline
\end{tabular}

Table 3. Matrix of values for landscape composition [64, p. 27].

\begin{tabular}{l|c|c|c|c|}
\hline \multirow{2}{*}{$\begin{array}{l}\text { Density of } \\
\text { housing/vegetation }\end{array}$} & $\begin{array}{l}\text { Dispersed housing } \\
\text { areas }\end{array}$ & $\begin{array}{l}\text { Loose housing } \\
\text { areas }\end{array}$ & $\begin{array}{l}\text { Compact housing } \\
\text { areas }\end{array}$ \\
\cline { 3 - 5 } & 3 & 3 & 2 & 1 \\
\hline compact & 3 points & 5 points & 4 points \\
\hline loose & 2 & 5 points & 4 points & 3 points \\
\hline dispersed & 1 & 4 points & 3 points & 2 points \\
\hline
\end{tabular}

The next step in the research included the assessment of the visual landscape capacity in terms of terrain construction, the height of the existing vegetation and construction as well as the artwork of elements creating the landscape. The results of the conducted analysis were matched with the matrices adequate for each factor (Tables 1-3).

The third phase of analyses concerned landscape capacity assessment resulting from exposure. The main assumption underlying this assessment is the fact that the more the area is visible from various observation points, the more difficult it is to hide any changes occurring on it. The assessment was performed from 16 observation points designated in 3 distance zones (Fig. 2). The opening of the terrain was studied in three scales: total, partial, and none.

The final phase of the research was adding up all of the results obtained from the different phases of the analysis of the landscape capacity, which results from historical value, visual capacity, and exposure.

\section{Results and Discussion}

\section{Landscape Capacity Resulting from Historical Value}

The basis for the assessment we conducted was land cover maps from 1926, 1940, and 2014 (Fig. 3). It was on their basis that the indicator of land cover variations was designated. The results have been summarized in 

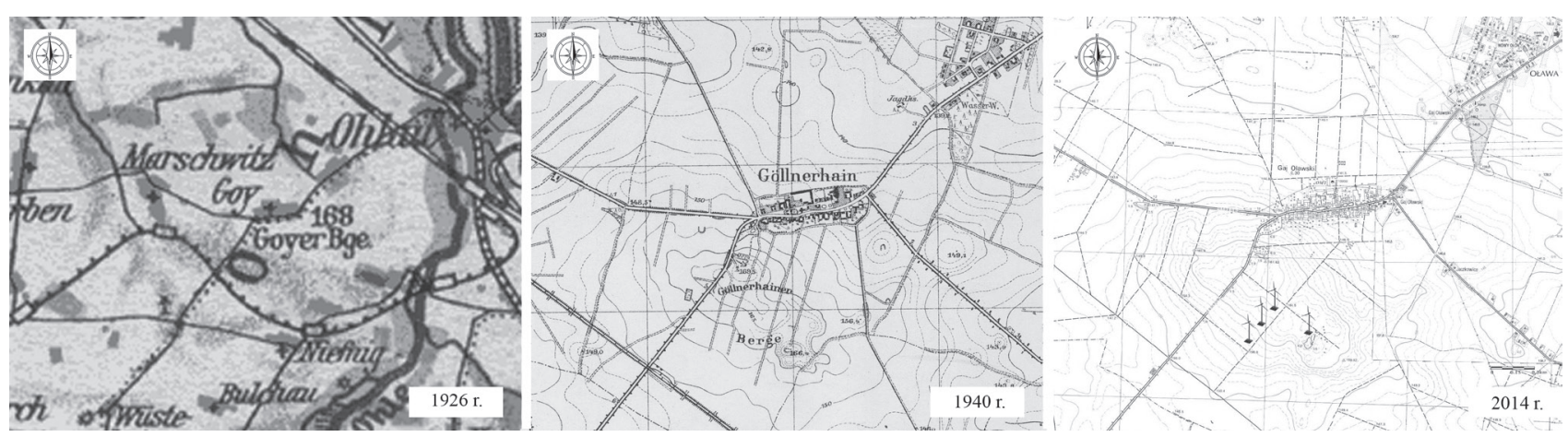

Fig. 3. Land cover maps dated: 1926, 1940 and 2014. Source: http://dolny-slask.org.pl/mapy.action, http://amzpbig.com/maps/5069_ Ohlau 1940.jpg, http://mapy.geoportal.gov.pl/imap/?gpmap=gp0\&actions=acShowWgButtonPanel kraj_ORTO

tabular form (Table 4), and they show that on terrain subject to research, the average historical value resulting from residential construction as well as vegetation is prevailing, that is, in this respect the landscape shows average capacity. Farmlands show low historical value, which means a high landscape capacity.

\section{Visual Capacity}

On the basis of maps, matrices, assessment criteria for the landscape capacity [64], previously collected information, and the vision in the field, research shows that the average decrease for the terrain construction with the southern slope is $4-8 \%$ - that is 5 points. The height of the vegetation near the wind farm exceeds $5 \mathrm{~m}$, and the height of the existing construction is maximally 2 storeys, so the matrices' value equals 3 points. The last criterion considered in the analysis of the visual capacity is the composition of elements. Both construction as well vegetation on the area subject to research are of a compact nature and occur to the north of the wind farm. In view of the above, the point value for the landscape composition is 4 . The sum of the points awarded is 12 , which means that the area subject to research has an average visual capacity.

\section{Landscape Capacity Resulting from Exposure}

Figs 4-19 present the evaluation results of landscape capacity arising from exposure. The dotted white line indicates the fan base, and the dotted black line indicates its highest point.

An analysis of landscape capacity arising from exposure allows us to conclude that the landscape has

Table 4. Assessment of landscape capacity resulting from historical value (prepared by the author).

\begin{tabular}{|c|c|c|c|c|c|c|c|c|}
\hline \multirow{2}{*}{ Land cover } & \multicolumn{3}{|c|}{$\begin{array}{c}\text { 1. Land cover map (\%) } \\
\text { (given in hectares in parentheses) }\end{array}$} & \multicolumn{2}{|c|}{ 2. Degree of deviation } & \multirow{2}{*}{$\begin{array}{c}\text { 3. Indicator of } \\
\text { landscape } \\
\text { variation }\end{array}$} & \multirow{2}{*}{$\begin{array}{c}\text { Evaluation } \\
\text { of historical } \\
\text { value }\end{array}$} & \multirow{2}{*}{$\begin{array}{l}\text { Landscape } \\
\text { capacity }\end{array}$} \\
\hline & 1926 & 1940 & 2014 & $\begin{array}{c}\text { Degree of } \\
\text { deviation in } \\
\text { 1926: } 1940\end{array}$ & $\begin{array}{l}\text { Degree of } \\
\text { deviation in } \\
\text { 1940: } 2014\end{array}$ & & & \\
\hline $\begin{array}{l}\text { Residential } \\
\text { construction }\end{array}$ & $\begin{array}{c}13.40 \\
(118.70)\end{array}$ & $\begin{array}{c}3.31 \\
(29.31)\end{array}$ & $\begin{array}{c}3.91 \\
(34.67)\end{array}$ & -10 & 1 & 11 & $\begin{array}{l}\text { average his- } \\
\text { torical value }\end{array}$ & $\begin{array}{c}\text { Average } \\
\text { historical value } \\
\text { of the landscape } \\
\text { indicates average } \\
\text { landscape } \\
\text { capacity }\end{array}$ \\
\hline Farmlands & $\begin{array}{c}71.68 \\
(634.73)\end{array}$ & $\begin{array}{c}93.96 \\
(832.07)\end{array}$ & $\begin{array}{c}93.12 \\
(824.58)\end{array}$ & 22 & -1 & 23 & $\begin{array}{l}\text { the low his- } \\
\text { torical value }\end{array}$ & $\begin{array}{l}\text { Low historical } \\
\text { value of the } \\
\text { landscape } \\
\text { indicates high } \\
\text { landscape } \\
\text { capacity }\end{array}$ \\
\hline Vegetation & $\begin{array}{c}14,92 \\
(132,11)\end{array}$ & $\begin{array}{c}2,73 \\
(24,16)\end{array}$ & $\begin{array}{c}2,97 \\
(26,29)\end{array}$ & -12 & 0 & 12 & $\begin{array}{l}\text { average his- } \\
\text { torical value }\end{array}$ & $\begin{array}{c}\text { Average value } \\
\text { of the landscape } \\
\text { indicates average } \\
\text { landscape } \\
\text { capacity }\end{array}$ \\
\hline
\end{tabular}


a high capacity at a distance of more than $5 \mathrm{~km}$ away from the windfarm (10-16 observation points, Fig. 1319). In the case of only two observation points (11 and 12) located to the east of the research subject, the landscape capacity was assessed as partial. Due to terrain

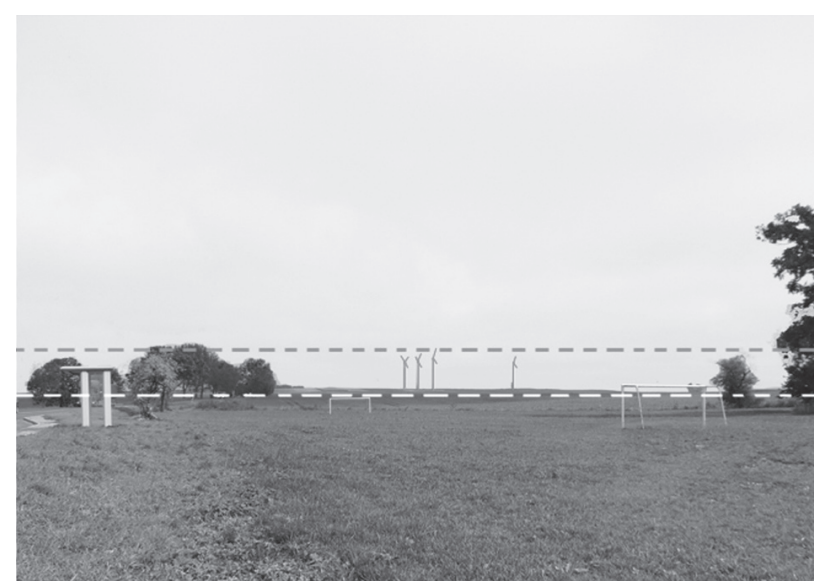

Fig. 4. Observation point No. 1 - partial visibility, average capacity.

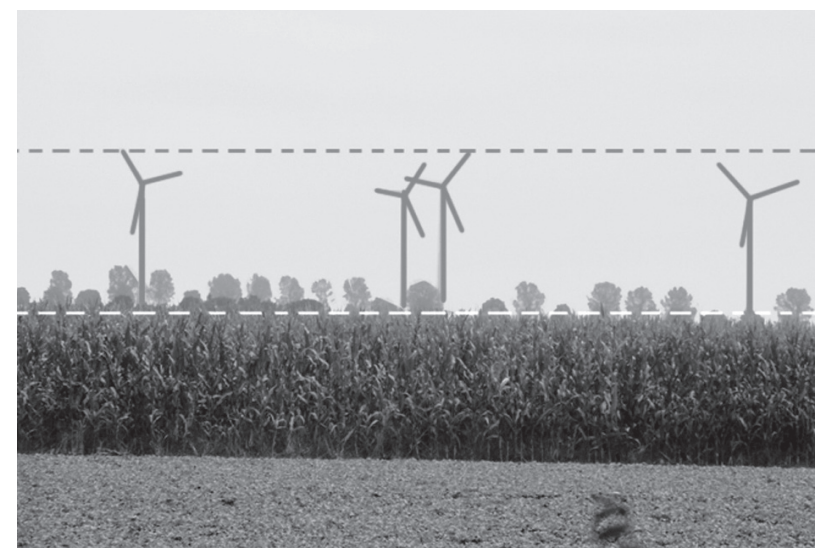

Fig. 5. Observation point No. 2 - total visibility, low capacity.

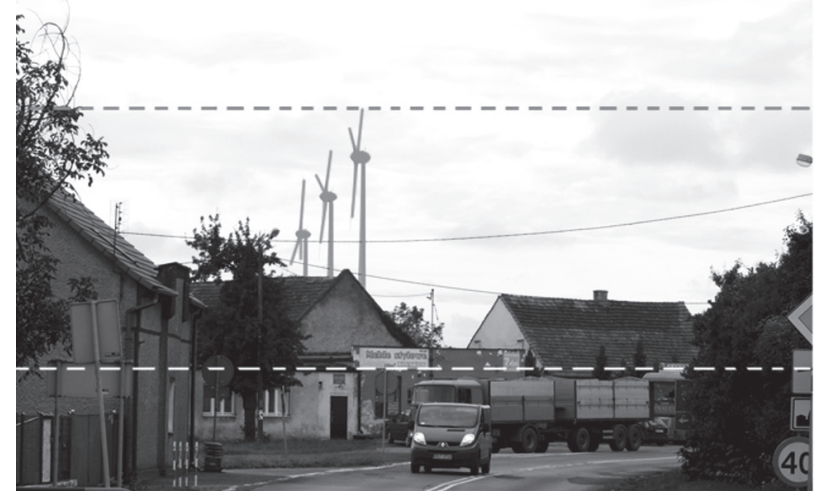

Fig. 6. Observation point No. 3 - partial visibility, average capacity. construction and differences in the height from other observation points located at a distance of more than $5 \mathrm{~km}$, the fans are invisible.

In the nearest zone up to $2 \mathrm{~km}$ from the farm (Figs 4-7) as well as in zone 2 (5 km; Figs 8-12), landscape

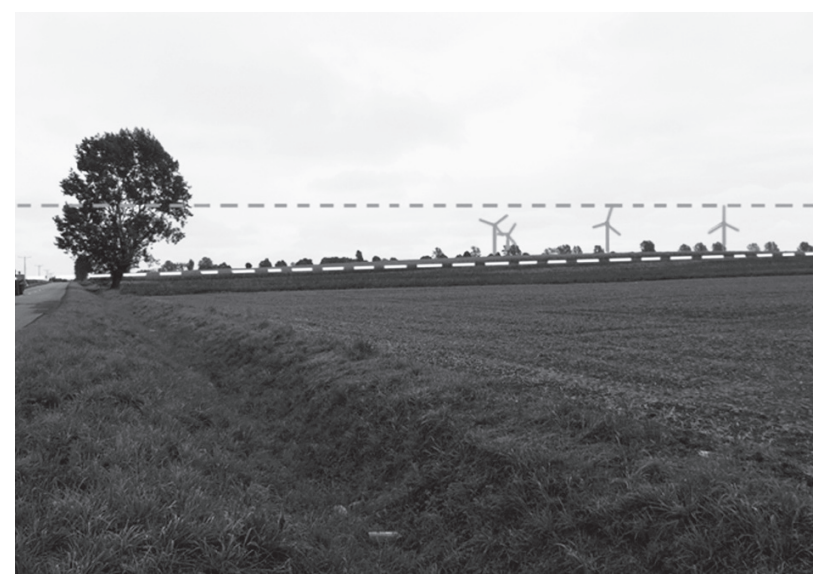

Fig. 7. Observation point No. 4 - partial visibility, average capacity.

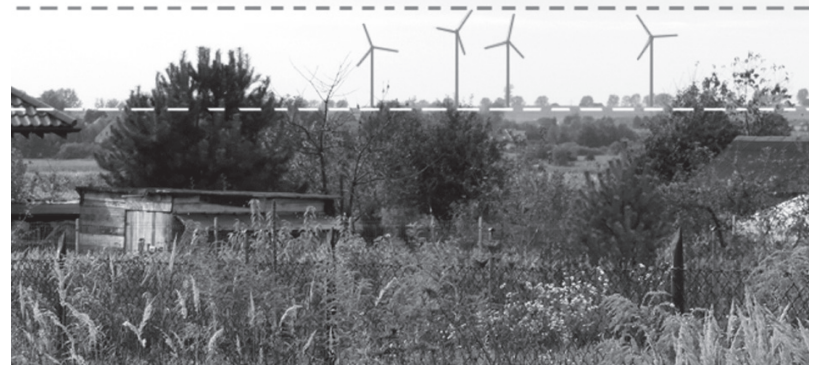

Fig. 8. Observation point No. 5 - partial visibility, average capacity.

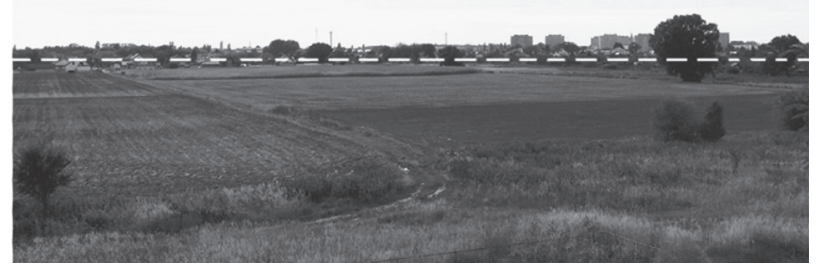

Fig. 9. Observation point No. 6 - no visibility, high capacity. 
capacity is at a medium level. In the zone of up to $2 \mathrm{~km}$, low landscape capacity was reported only at observation point No. 2 (Fig. 5). On the other hand, in the observation zone of 2 to $5 \mathrm{~km}$, the low capacity is specified for point No. 7 (Fig. 10) and high capacity for observation point No. 6 (Fig. 9).

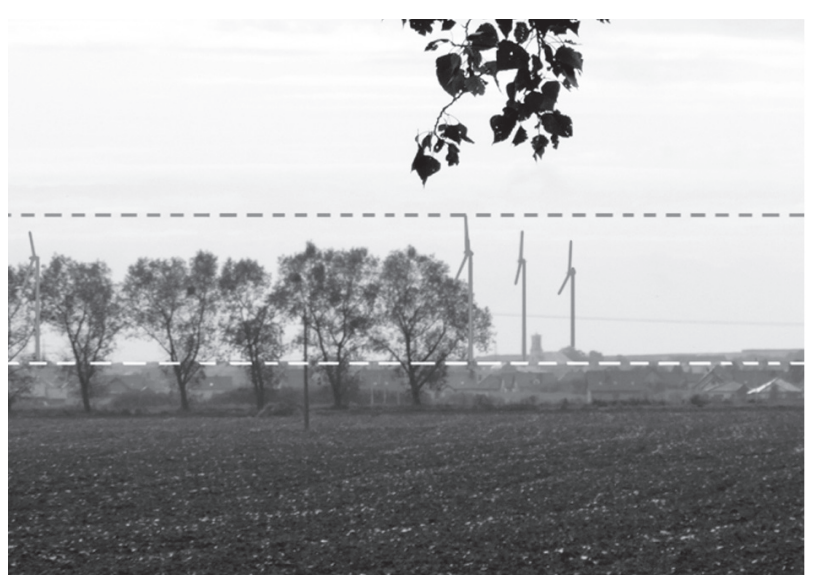

Fig. 10. Observation point No. 7 - total visibility, low capacity.

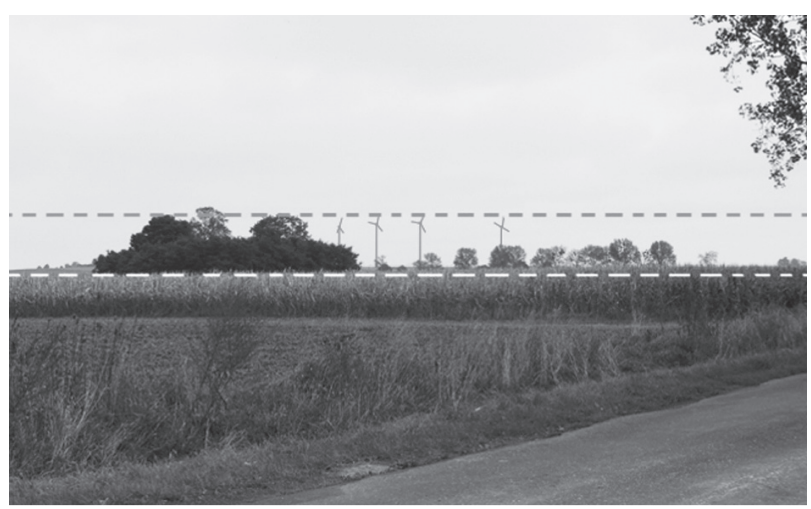

Fig. 11. Observation point No. 8 - partial visibility, average capacity.

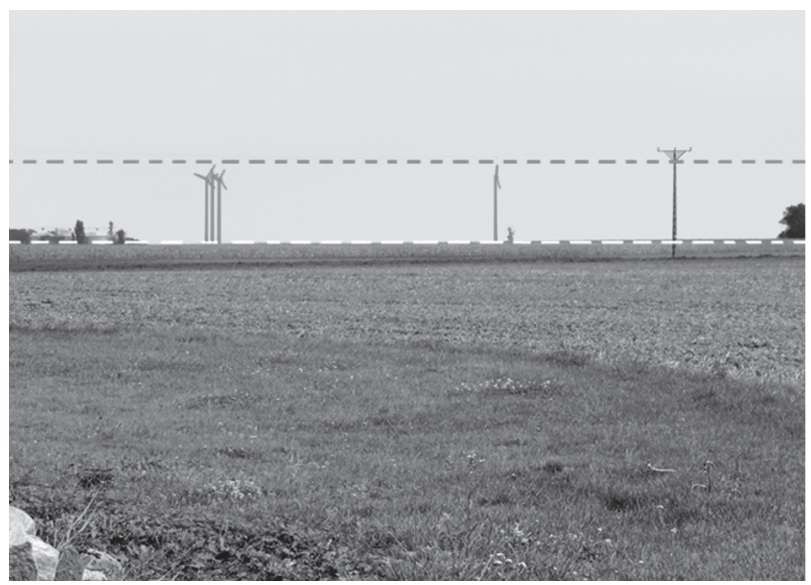

Fig. 12. Observation point No. 9 - partial visibility, average capacity.
The method used in the dissertation constitutes one of the opinions in the discussion on the assessment method of human activity impact on the landscape changes. According to Krajewski [64], its application should be associated with the creation of the landscape study in the planning process. Krajewski [64] claims that it can be used

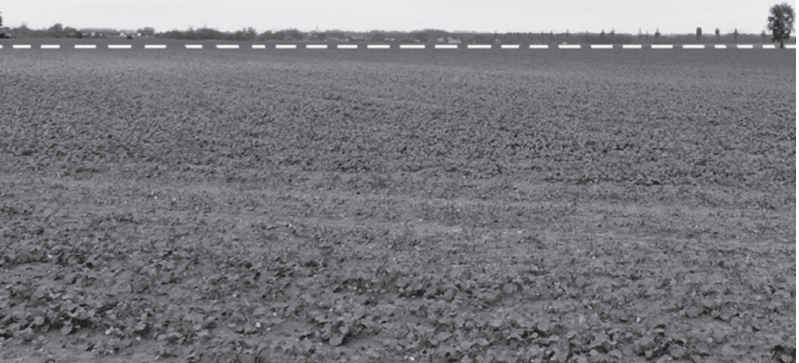

Fig. 13. Observation point No. 10 - no visibility, high capacity.

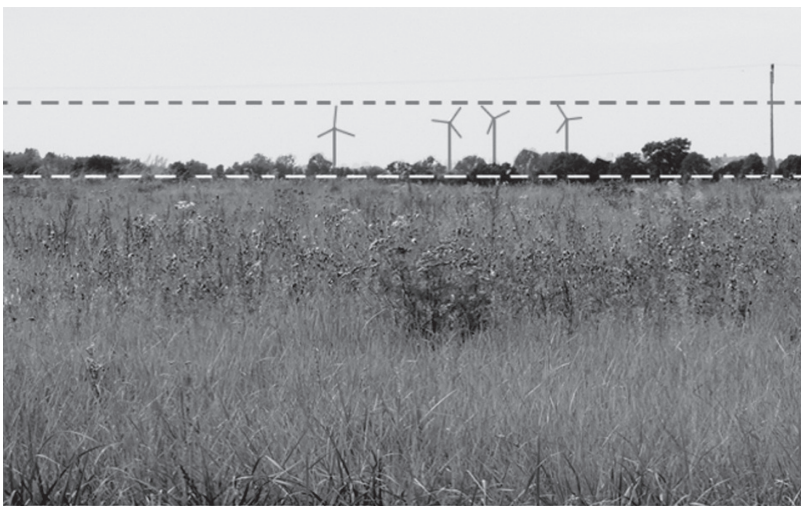

Fig. 14. Observation point No. 11 - partial visibility, average capacity.

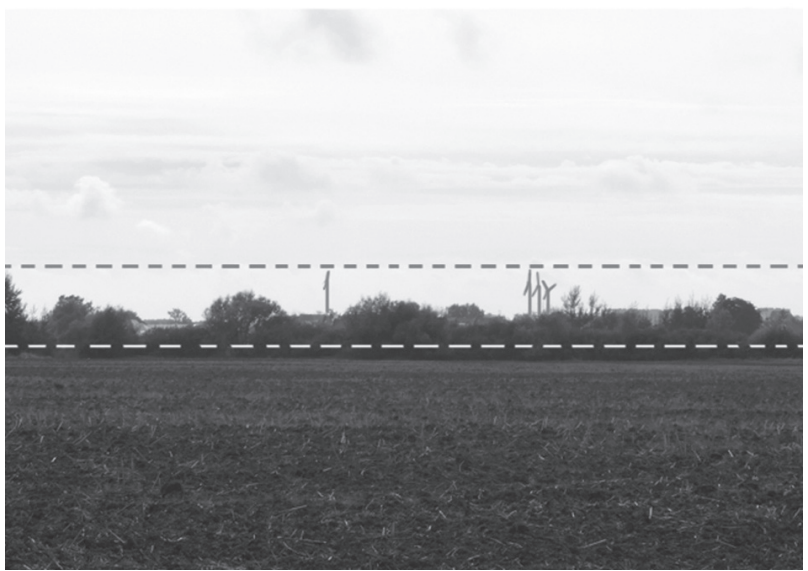

Fig. 15. Observation point No. 12 - partial visibility, average capacity. 
on the stage of the development of the ecophysiografical study, the prognosis of the impact of planning documents on the environment is also used to verify the existing planning records or to indicate the most appropriate location for the built-up areas.

In this paper, the authors attempted to evaluate the applicability of the Polish method to determine the influence of wind farm investment on the landscape using Krajewski's landscape capacity method [64]. The results do not allow us to fully determine this impact. In the analysis of the impact of the investment on the landscape, the search for the relationship of the potential/ existing landscape investment, in which this investment is to be created or exists, is essential. The method used in the dissertation refers, to a slight extent, to the nature of the investment and to the type of the landscape in which it is located. Especially at the stage of the assessment of landscape capacity arising from exposure, the assessment of the relationships between the elements assessed and other landscape elements that may significantly expose or balance the impact of the investment is missing.

In 2015 Hurtado et al. [26] proposed a clear and objective method that allows us to estimate the visual impact generated by the wind farm on neighbouring areas, called the visual impact evaluation matrix (VIEM). This method takes into account the nature of the investment,

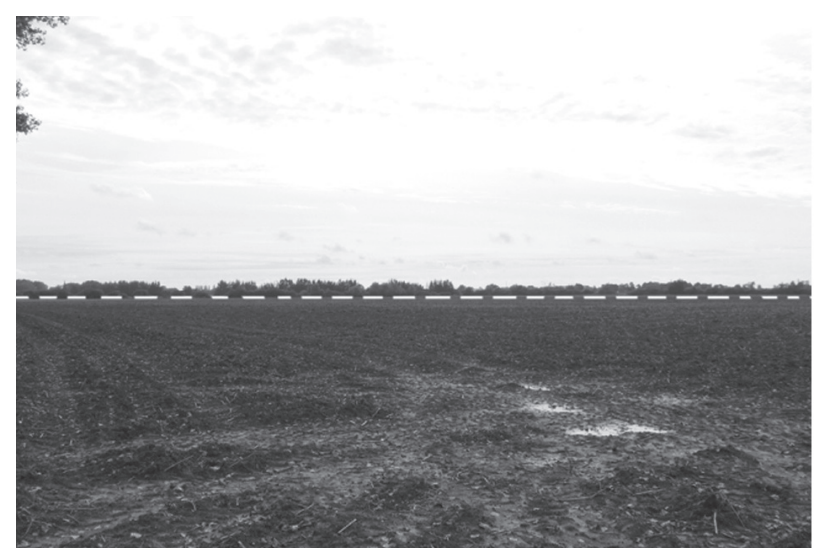

Fig. 16. Observation point No. 13 - no visibility, high capacity.

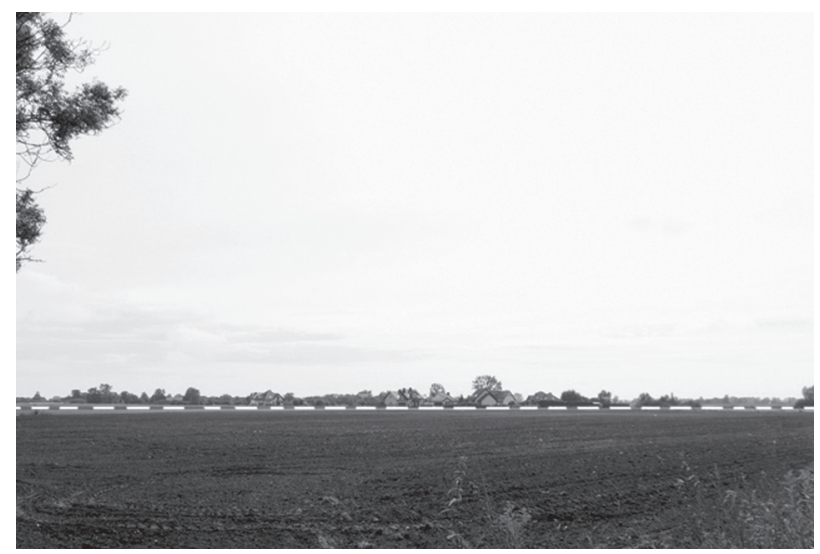

Fig. 17. Observation point No. 14 - no visibility, high capacity. its size and the angle of observation (frontal, diagonal, longitudinal), and the distance of observation visibility coefficient of wind farm from village, visibility coefficient of village from wind farm). The distance of observation is a factor taken into account in this method but also in other research [18, 26-27, 59]. All authors explicitly point out that the visual impact of investment decreases as the distance of observation increases. Studies conducted in recent years show a reduction in the visual effect already at a distance of 2-5 km, while Molina-Ruiz and others [27] indicate that at up to $10 \mathrm{~km}$ of distance, the potential visual impact is high, from $10 \mathrm{~km}$ to $20 \mathrm{~km}$ the visual effect is intermediate, and for greater distances it is low. If the distance exceeds $30 \mathrm{~km}$, there is no visible impact. The method proposed by Hurtado et al. [26] also takes into account the power of impact on people by determining the number of people observing a wind farm, and this aspect is being raised by many otherss [18, 27]. The nature of the investment reflecting the number of windmills [26] and their size [27], as well as the contrast between installation color and background [6, 27, 59] highlight the aesthetic aspects of integrating wind farms into the landscape by using photographs and interviews to develop an objective indicator based on parameters such as visibility, colour, fractality, and concurrence between fixed and mobile panels.

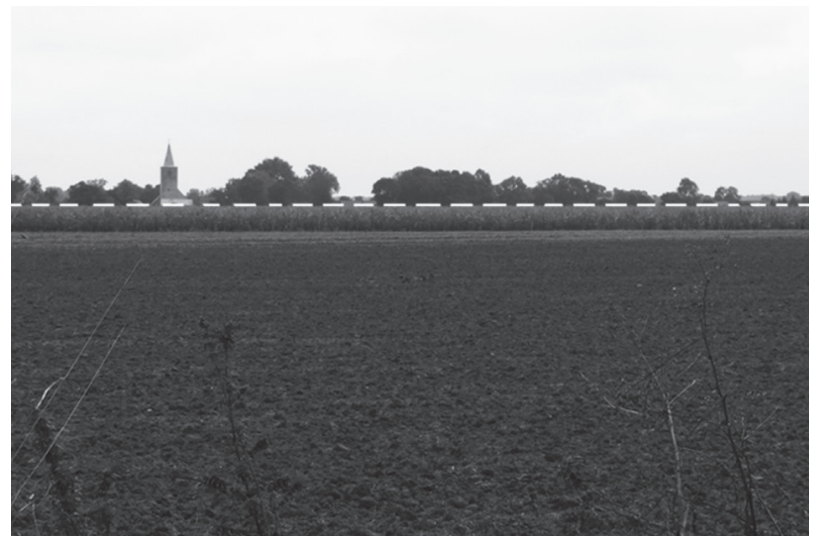

Fig. 18. Observation point No. 15 - no visibility, high capacity.

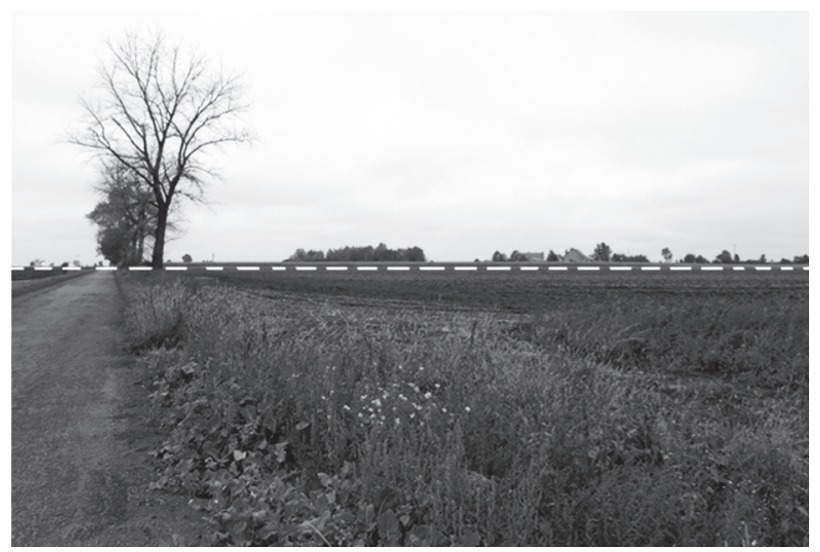

Fig. 19. Observation point No. 16 - no visibility, high capacity. 
Table 5. Overview of criteria for visual impact assessment on landscape and cultural heritage in guidelines and policy; documents from different countries [70].

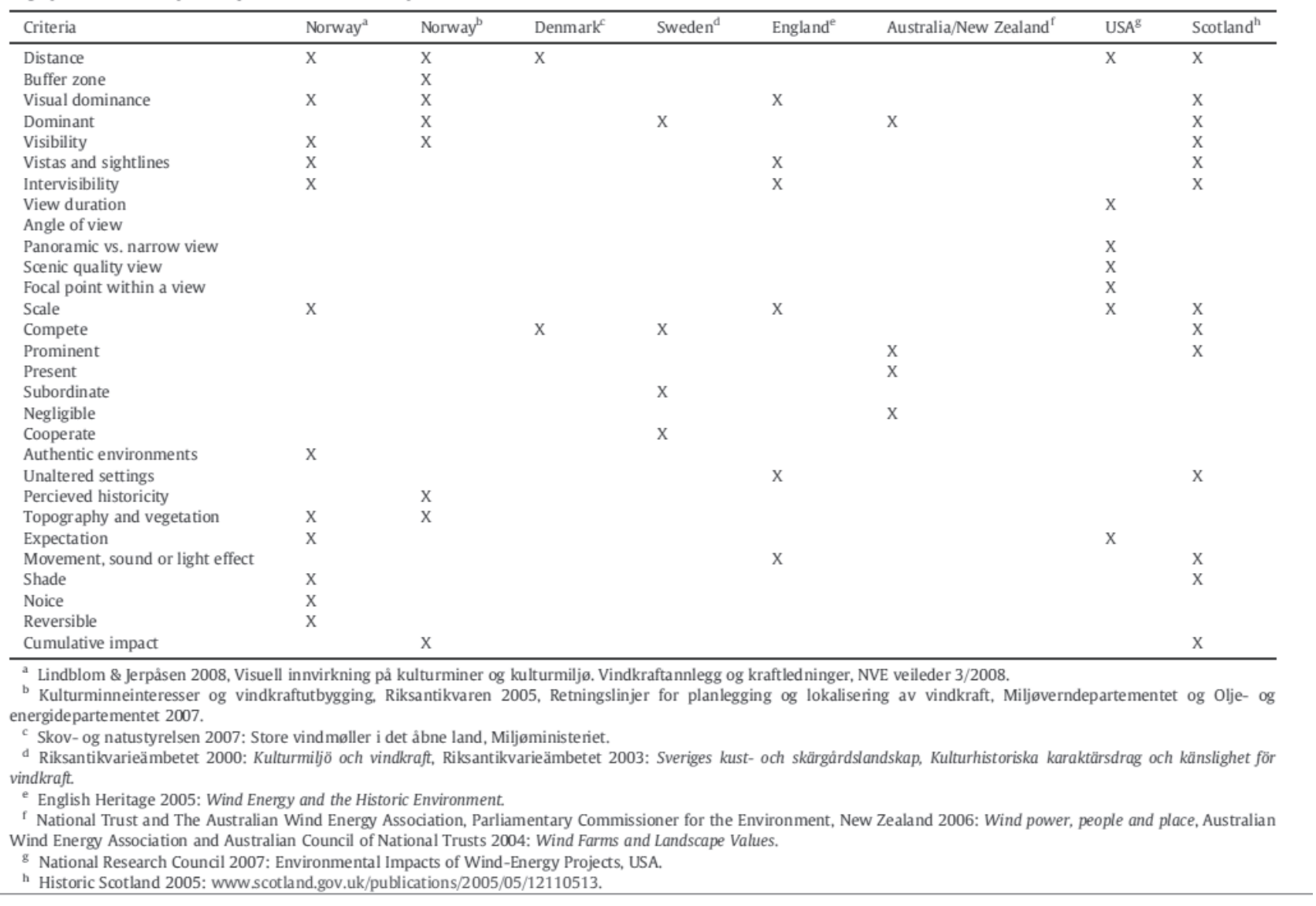

The analysis did not allow us to clearly answer how big the impact of the wind farm in Gaj Oławski on the existing landscape might be. Certain methodological shortcomings in the applied method were noticed, including at the stage of adding all of the values of the three partial assessments estimating the sensitivity level, and the fact that no reference to the final classification of the landscape sensitivity level appears. This, in turn, entails the inability to determine the overall landscape capacity. Unfortunately, as is shown by Churchward et al. [68], Palmer [14], and Palmer and Hoffman [69], among others, methodological shortcomings are a commonality among many researches in the world as they do not meet the standards that can be expected from the methods used to assist in making important planning decisions impacting the public landscape. Hau [39 after: 25] considers that the most difficult of all environmental impact assessments for wind turbines is assessing its visual impact.

As shown by Jerpĺsen and Larsen [70], worldwide research on the methods of assessing the impact of investment on the landscape reaches for various criteria that can be divided into: physical features of the landscape (e.g., topography and vegetation), features related to characteristics of the investment (e.g., scale, movement, sound or light effect) and features linked to perception conditions (distance, vistas, and sightlines or panoramic vs. narrow views) (Table 5). Some authors have criticized methods. They believe that the opinion polls can be an alternative to this type of research, including Churchward et al. [68], among others, who indicate that there is an extensive amount of research demonstrating the reliability and validity of publishing photos and photorealistic imagery as a means of determining scenic landscape value. Jones and Eiser [17] and Knopper et al. [12] show that public opinion polls are important in assessing investments at the phase of planning. However, human evaluations are not very complex because they depend on subjective perception of the landscape, not as a neutral area in which processes and functions are developed, but as part of the "living space" where individuals have their own perception and relationships with the environment [18]. It seems that a comprehensive method should combine expert methods with the opinions of potential users. There are 6 factors that should be taken into account when assessing the impact of wind power plant on the landscape [after: 14, p. 57]:

A) The significance of the potentially affected scenic resource of state or national significance.

B) The existing character of the surrounding area.

C) The expectations of the typical viewer.

D) The expedited wind energy development's purpose and the context of the proposed activity.

E) The extent, nature, and duration of potentially affected public uses of the scenic resource of state or national 
significance and the potential effect of the generating facilities' presence on the public's continued use and enjoyment of the scenic resource of state or national significance.

F) The scope and scale of the potential effect of views of the generating facilities on the scenic resource of state or national significance, including but not limited to issues related to the number and extent of turbines visible from the scenic resource of state or national significance, the distance from the scenic resource of state or national significance, and the effect of prominent features of development on the landscape. Krajewski's method [64] partly reflects criterion B, but other aspects are not included in this method.

\section{Conclusions}

Wind farms are undoubtedly an element that strongly interfere with landscapes, but we can try to minimize this by looking for a suitable investment location depending on the type of landscape, the terrain, and the spatial relationships of its components. In this aspect, the method used in work seems to have an application relevance.

The assessment of landscape capacities could be part of a comprehensive assessment of the impact of landscape investments, as in the work of Molina-Ruiz et al. [27]. Further research on developing the Polish methodology for assessing the impact of investment on the landscape should be continued, drawing on the experience and results of global research in this field.

\section{References}

1. SMART D.E., STOJANOVIC T. A., WARREN CH.R. Is EIA part of the wind power planning problem? Environ. Impact Asses. 49, 13, 2014.

2. BRIDGE G, BOUZAROVSKI S, BRADSHAW M, EYRE N. Geographies of energy transition: space, place and the low-carbon economy. Energ. Policy 53, 33, 2013.

3. PACHAURI R.K., REISINGER A. Climate Change 2007: Synthesis report. Contribution of working groups I, II and III to the fourth assessment report of the intergovernmental panel on climate change. Intergovernmental Panel on Climate Change; 1, Switzerland, 2007.

4. JACOBSON M.Z., ARCHER C.L. Saturation wind power potential and its implications for wind energy. Proc. Natl. Acad. Sci. U. S. A. 109 (39), 15679, 2012.

5. TABASSUM-ABBAS I, PREMALATHA M., TASNEEM ABBAS, ABBASI S.A. Wind energy: Increasing deployment, rising environmental concerns. Renew. Sust. Energ. Rev. 31, 270, 2014.

6. TORRES SIBILLE A.C, CLOQUELL-BALLESTER V.A., CLOQUELL-BALLESTER V.A., DARTON R.C. Development and validation of a multicriteria indicador for the assessment of objective aesthetic impact of wind farms. Renew. Sust. Energ. Rev 13, 40, 2009.

7. STRYJECKI M, MIELNICZUK K. Guidelines for forecasting impacts on environment of the wind farms,
Generalna Dyrekcja Ochrony Środowiska, Departament Ocen Oddziaływania na Środowisko, Poland, 2011.

8. McGOWAN F., SAUTER R. Public opinion on energy research: A desk study for the research councils. England, 2005.

9. DEVINE-WRIGHT P. Reconsidering public attitudes and public acceptance of renewable energy technologies: A critical review. University of Manchester, England, 2007.

10. JONES C. R., EISER J. R. Identifying predictors of attitudes towards local on shore wind development with reference to an English case study. Energ. Policy 37 (11), 4604, 2009.

11. SWIM J., CLAYTON S., DOHERTY T., GIFFORD R., HOWARD G., RESER J., STERN P., WEBER E. Psychology and global climate change: Addressing a multifaceted phenomenon and set of challenges. A report by the American Psychological Association's task force on the interface between psychology and global climate change; USA, 2009.

12. KNOPPER L.D., OLLSON C.A., MCCALLUM L.C., WHITFIELD-ASLUND M.L., BERGER R.G., SOUWEINE K., McDANIEL M. Wind turbines and human health. Front. Public Health 2 (63), 2014.

13. MAEH A.M., WATTS G.R., HANRATTY J., TALMI D. Emotional response to images of wind turbines: A psychophysiological study of their visual impact on the landscape. Landscape Urban Plan. 142, 71, 2015.

14. PALMER J.F. Effect size as a basis for evaluating the acceptability of scenic impacts: Ten wind energy projects from Maine, USA. Landscape Urban Plan. 140, 56, 2015.

15. KONDILI E., KALDELLIS J.K. 2.16-Environmentalsocial benefits/impacts of wind power. In: SAYIGH A. (Ed.), Comprehensive renewable energy; 503, Netherlands, UK, USA, 2012.

16. WOLSINK M. Wind power and the NIMBY-myth: Institutional capacity and the limited significance of public support. Renew. Energ. 21 (1), 49, 2000.

17. JONES C.R., EISER J.R. Understanding 'local' opposition to wind development in the UK: How big is a backyard? Energ. Policy 38 (6), 3106, 2010.

18. RODRIGUES M., MONTAÑÉS C., FUEYO N. A method for the assessment of the visual impact caused by the largescale deployment of renewable-energy facilities. Environ. Impact Asses. 30, 240, 2010.

19. DE VRIES S., DE GROOT M., BOERS J. Eyesores in sight: Quantifying the impact of man-made elements on the scenic beauty of Dutch landscapes. Landscape Urban Plan. 105 (1), 118, 2012.

20. MAFFEI L., IACHINI T., MASUlLO M., ALETTA F., SORRENTINO F., SENESE V.P., RUOTOLO F. The effects of vision-related aspects on noise perception for wind turbines in quiet areas. Int. J. Env. Res. Pub. He. 10 (5), 1681, 2013.

21. WATTS G.R., PHEASANT R.J. Factors affecting tranquillity in the countryside. Appl. Acoust. 74 (9), 1094, 2013.

22. KROHN S., DAMBORG S. On public attitudes towards wind power. Renew. Energ. 16 (1), 954, 1999.

23. CASS N., WALKER G. Emotion and rationality: The characterisation and evaluation of opposition to renewable energy projects. Emotion, Space and Society 2, 62, 2009.

24. BAKKER R.H., PEDERSEN E.B., VAN DEN BERG G.P., STEWART R.E., LOK W., BOUMA J. Impact of wind turbine sound on annoyance, self-reported sleep disturbance and psychological distress. Sci. Total Environ. 425, 442, 2012. 
25. LEUNG D.Y.C., YUAN YANG. Wind energy development and its environmental impact: A review. Renew. Sust. Energ. Rev 16, 1031, 2012.

26. HURTADO J.P., FERNANDEZ J., PARRONDO J.L., BLANCO E. Spanish method of visual impact evaluation in wind farms. Renew. Sust. Energ. Rev 8, 483, 2004.

27. MOLINA-RUIZ J., MARTÍNEZ-SÁNCHEZ M.J., PÉREZSIRVENT C., TUDELA-SERRANO M.L., LORENZO M.L.G. Developing and applying a GIS-assisted approach to evaluate visual impact in wind farms. Renew. Energ. 36, 1125,2011

28. SAIDUR R., RAHIM N.A., ISLAM M.R., SOLANGI K.H. Environmental impact of wind energy. Renew. Sust. Energ. Rev 15 (5), 2423, 2011.

29. FRANTA L.B., KUNC J. Wind turbines in tourism landscapes Czech experience. Ann. Tourism Res. 38 (2), 499, 2011.

30. PERCIVAL S.M. Bird and wind turbines in Britain. British Wildlife 12, 8, 2000.

31. PERCIVAL S.M. Novar Wind Farm proposed extension: ornithological assessment. Report to National Wind Power Ltd., Ireland, 2002.

32. CHYLARECKI P. Guidelines for assessing the impact of wind farms on birds. PSEW, Poland, 2008.

33. LUCA M., JANSS G., WHITFIELD D., RERRER M. Collision fatality of raptors in wind farms does not depend on raptor abundance. J. App. Ecol. 45 (6), 1695, 2008.

34. WUCZYNSSKI A. The impact of wind farms on birds. Types of interactions, their significance for bird populations and practice of research in Poland. Notatki Ornitologiczne 50, 206, 2009.

35. ARNOLD T.W., ZINK R.M. Collision mortality has no discernible effect on population trends of North American birds, PLoS 6 (9), 2011

36. CHANG T., NIELSEN E., AUBERLE W., SOLOP F.I. A quantitative method to analyze the quality of EIA information in wind energy development and avian/bat assessments. Environ. Impact Asses. 38, 142, 2013.

37. TRYJANOWSKI P. Discussion materials on bird mortality caused by collisions with wind turbines. http://wyslijto.pl/ download/xe1rw5xrtf, 2013.

38. BADORA K. Wind farms as elements that determine the structure and function of rural landscapes. Landscape Architecture 2, 60, 2013.

39. HAU E. Wind turbines. Springer, Germany, 2000.

40. MC DERMOTT M. Texas wind farm uses NASA radar to prevent bird deaths. Available from: http://www.treehugger. com/files/2009/05/texas-wind-farm-uses-nasa-radarprevent-bird-deaths.php, 2009.

41. THE GLOBAL WIND ENERGY COUNCIL (GWEC). Birds and bats. Available from: http://www.gwec.net/index. php?id=144, 2010.

42. KNOPPER L.D., OLLSON C.A. Health effects and wind turbines: A review of the literature. Environ. Health 10 (78), 2011.

43. SHEPHERD D., MCBRIDE D., WELCH D., DIRKS K.N., HILL E.M. Evaluating the impact of wind turbine noise on health-related quality of life. Noise Health 13 (57), 333, 2011.

44. TORRANCE E.P., GOFF K. A quiet revolution. Engineering and Technology 10, 44, 2009.

45. FIUMICELLI D. Windfarm noise dose response: a literature review. Acoustics Bulletin 26, 2011.

46. LEE S, KIM K, CHOI W. Annoyance caused by amplitudę modulation of wind turbine noise. Noise Control Eng. J. 59 (1), 38, 2011.
47. PEDERSEN E. Health aspects associated with wind turbine noise. Results from three field studies. Noise Control Eng. J. 59 (1), 47, 2011.

48. MALCZYK T. Eco energy anthropopression in the landscape for example the wind park "Lipniki", Landscape Architecture 3, 37, 2013.

49. ORZECHOWSKA-SZAJDA I., PODOLSKA A. Assessment criteria for the impact of large-scale investment on the landscape based on Visual Resource Management (VRM), Landscape Architecture 3, 66, 2013.

50. TSOUTSOS T., TSOUCHLARAKI A., TSIROPOULOS M., SERPETSIDAKIS M.. Visual impact evaluation of a wind park in a Greek island. Appl. Energ. 86 (4), 546, 2009.

51. BACON W.R. The Visual Management System of the Forest Service, USDA. [In:] ELSNER, GARY H., SMARDON R.C., Proceedings of our national landscape. A Conference on Applied Techniques for Analysis and Management of the Visual Resource April 23-25 1979, 660, USA, 1979.

52. ROSS R.W. The Bureau of Land Management and Visual Resource Management - An Overview [In:] ELSNER, GARY H., SMARDON R.C, Proceedings of our national landscape. A Conference on Applied Techniques for Analysis and Management of the Visual Resource April 23-25 1979, 666, USA, 1979.

53. UNITED STATES DEPARTMENT OF THE INTERIOR - BUREAU OF LAND MANAGEMENT . Manual 8431 Visual Resource Contrast Rating. http://www.blm.gov/nstc/ VRM/vrmsys.html, USA, 1980a.

54. UNITED STATES DEPARTMENT OF THE INTERIOR - BUREAU OF LAND MANAGEMENT. Manual H-8410-1 - Visual Resource Inventory. U.S. Department of the Interior, USA, 1980b ..

55. BLOCKER L., SLIDER T., RUCHMAN J., MOSIER J., KOK L., SILBEMAGLE J., BEARD J., WAGNER D., BROGAN G., JONES D., LAUGHLINN N., ANDERSON L. Landscape Aesthetics (AH 701-f) - Scenery Management System Application (Chapter 5). USDA Forest Service, USA, 1995

56. SWANWICK C. Landscape Character Assessment. Guidance for England and Scotland. UK, 2002.

57. ORZECHOWSKA-SZAJDA I. Visual Resource Management and its application in the assessment of the impact of large-scale investments on the landscape.. Available from: http:/ochronaprzyrody.gdos.gov.pl/files/ artykuly/44524/Iwona_Orzechowska_Szajda.pdf, Poland, 2015.

58. BABAN S.M.J., PARRY T. Developing and applying a GIS-assisted approach to locating wind farms in the UK. Renew. Energ. 24, 59, 2001.

59. MÖLLER B. Changing wind-power landscapes: regional assessment of visual impact on land use and population in Northern Jutland, Denmark. Appl. Energ. 83 (5), 477, 2006.

60. BAJEROWSKI T., SENATRA A., SZCZEPAŃSKA A. Wycena krajobrazu. Rynkowe aspekty oceny i waloryzacji krajobrazu. Poland, 2000.

61. BOGDANOWSKI J. . Method of architectural and landscape units and interiors (JARK-WAK) in studies and design.Politechnika Krakowska, Poland, 1999.

62. MYGA-PIĄTEK U. The Criteria and methods of the assessment of cultural landscape valorization in the process of spatial planning in view of effective legal procedures In: The Valorization of natural habitat in spatial planning. Kistowski M., Korwel-Lejkowska B. (Ed.) The Problems of Landscape Ecology - volume XIX. The Institute of Geography at Gdańsk University, The Polish Association of 
Landscape Ecology, The Committee „Human and Nature” The Presidium PAN. Gdańsk-Warszawa,101, Poland, 2007.

63. OZIMEK A, OZIMEK P., ŁABĘDŹ P. Scenic analyses with application of digital tools. Landscape Architecture 3, 4, 2012.

64. KRAJEWSKI P. Possible Applications of Landscape Capacity Assessment in Spatial Planning in Suburban Areas. Landscape Architecture 3, 22, 2012.

65. POTYRAŁA J., NIEDŹWIECKA-FILIPIAK I., ZIEMIAŃSKA M. Valorisation of views as an element of the landscape study on the example of community Paczków. Landscape Architecture 3, 13, 2012.

66. BADORA K. Methodology for assessing the impact of wind farms on the landscape. Available from: http:// ochronaprzyrody.gdos.gov.pl/files/artykuly/44524/ Krzysztof_Badora.pdf, Poland, 2015.
67. SCOTTISH NATURAL HERITAGE. Visual assessment of windfarms: best practice. University of Newcastle; Scotland, 2002.

68. CHURCHWARD C., PALMER J.F., NASSAUER J.I., SWANWICK C.A. Evaluation of methodologies for visual impact assessments (NCHRP report 741). DC: National Academy of Sciences, Transportation Research Board; USA, 2013.

69. PALMER J.F., HOFFMAN R.E. Rating reliability and representation validity in scenic landscape assessments. Landscape Urban Plan. 54, 149, 2001.

70. JERPĹSEN G.B., LARSEN K.C. Visual impact of wind farms on cultural heritage: A Norwegian case study. Environ. Impact Asses. 31, 206, 2011. 